\title{
TEATRO-MENOR: CARTOGRAFIA EM ARTE E EXPERIMENTAÇÃO DE MULHERES EM SITUAÇÃO DE CÁRCERE
}

\author{
TEATRO-MENOR: CARTOGRAFÍA EN ARTE Y EXPERIMENTACIÓN DE \\ MUJERES EN SITUACIÓN DE CÁRCEL \\ STAGE-MINOR: CARTOGRAPHY IN ARTS AND WOMEN EXPERIMENTATION \\ IN JAIL SITUATION
}

Gabriela Pinheiro Soares

Fundação Gregório Baremblitt e Instituto Félix Guattari, Natal/RN, Brasil

Antônio Vladimir Félix-Silva e Martha Emanuela Soares da Silva Figueiró

Universidade Potiguar, Natal/RN, Brasil

\section{RESUMO}

Este trabalho parte de uma pesquisa intervenção em um presídio feminino do Rio Grande do Norte - Brasil, cujo objetivo é compreender os modos de viver e reinventar-se das mulheres presas. Trata-se de uma cartografia em teatro-experimentação a partir de uma experiência de estágio em Psicologia, no qual se articula corpo, arte e clínica, compondo o eixo gênero, sexualidades e intersecções. Utiliza-se da observação participante, do diário de atos e da arte em oficinas, objetivando acompanhar cuidadosamente processos em curso, mapear o território existencial das atrizes e possibilitar que linhas de fuga sejam produzidas, deixando vazar uma multiplicidade de vozes, devires. Os resultados: expressões do devir da sensibilidade das mulheres presas no cuidado com as outras, na troca de palavras de afeto, na experimentação de outras formas de relação com o corpo e com a sexualidade.

Palavras-chave: Direitos Humanos; gênero; produção de subjetividade; prisão; resistência.

\section{RESUMEN}

Este trabajo es parte de una investigación intervención en un cárcel femenino del Rio Grande del Norte Brasil, cuyo objetivo es comprender los modos de vivir y reinventarse de las mujeres presas. Se trata de una cartografía en teatro-experimentación a partir de una experiencia de estajeo en Psicología, en el cual se articula cuerpo, arte y clínica, componiendo el eje género, sexualidades e intersecciones. Se utiliza de la observación participante, del diario de actos y del arte en talleres, objetivando acompañar cuidadosamente procesos en curso, mapear el territorio existencial de las actrices y posibilitar que líneas de fuga sean producidas, dejando vasar una multiplicidad de voces, devenires. Los resultados: expresiones del devenir sensibilidad de las mujeres presas en el cuidado con las otras, en el cambio de palabras de afecto, en la experimentación de otras formas de relación con el cuerpo y con la sexualidad.

Palabras-clave: Derechos Humanos; género; producción de subjetividad; cárcel; resistencia.

\begin{abstract}
This work starts from a research-intervention in a female prison at Rio Grande do Norte - Brasil, whose goal is to understand imprisoned women ways of living and how they reinvent themselves. It's about a cartography in a stage-experimentation out of a trainee experience in psychology, through which body, arts and clinics are articulated, composing the axis among gender, sexualities and intersections. It is used participant observation, field diary and arts in workshops, aiming to carefully follow ongoing processes, letting escape a multiplicity of voices, being-becomings. The results: expressions of the being-becoming sensibility of imprisoned women in the care with each other, in changing words of affection, in experimenting other forms of relation with the body and sexuality.
\end{abstract}

Keywords: Human Rights; gender; subjectivity production; prison; resistance. 
Historicamente, a dificuldade de acesso aos direitos reconhecidos como direitos humanos tem demandando uma luta constante por parte das mulheres, presas ou não presas. Em tese, a prisão não deveria privar os presos e as presas do acesso aos direitos básicos, pois é apenas a liberdade - o direito de ir e vir - que estaria contida na condenação, e não a dignidade como ser humano e os direitos fundamentais.

Esta problemática é bastante complexa e implica falta de transformações estruturais na sociedade e a falta de políticas públicas voltadas para a multiplicidade de grupos sociais. No sistema penitenciário essa violência social se reflete em presídios superlotados, celas e alas pouco arejadas com questões de insalubridade, falta de assistência médica, educacional, social e assistência jurídica precária, além da falta de segurança que essa instituição causa entre e para além dos muros e das cercas das prisões: desde as rebeliões internas aos protestos urbanos e a fobia social dos que vivem em liberdade e dos que moram ao lado dos muros da prisão.

Paradoxalmente, no dia a dia, tanto dentro dos muros da prisão quanto fora, percebemos Práticas Sociais, não instituídas e regulamentadas como movimentos sociais, que as mulheres produzem como forma de resistir ao controle de seus corpos, desejos, subjetividade, como modo de produzir vida e inventar saúde. São essas Práticas Sociais instituintes que nortearão as falas, atos e gestos dos autores e atrizes desse teatro.

Escrito em diversas pessoas e diferentes tempos verbais, este artigo transversaliza a linguagem teatral, atualizando personagens e situações, para produzir uma narrativa acerca da história de uma aspirante a psicóloga e sua prática de estágio profissional. Por meio da arte, ela constrói com as mulheres presas uma cartografia em teatro-experimentação: experimentarse estagiária de Psicologia, experimentar-se atriz, experimentar-se mulher, experimentar-se presa e devir autora e possibilitar múltiplos devires e outras narrativas.

A proposta desse teatro-experimentação, teatrotexto, teatro-menor ${ }^{1}$ é possibilitar que linhas de fuga sejam produzidas, deixar vazar uma multiplicidade de vozes, devir. Ser tomado por um devir é desterritorializar-se, é deixar-se tomar por uma conexão de fluxos, de intensidades, de desejos no encontro com um ou com vários outros. É permitir-se sair de um "si mesmo" para o encontro com o estrangeiro, com o diferente, apagando linha por linha a figura atual que chamamos eu, até dar ensejo a uma forma completamente nova, com novos traços e riscados. "Podemos dizer que a cada vez que isto acontece, é uma violência vivida por nosso corpo em sua forma atual, pois nos desestabiliza e nos coloca a exigência de criarmos um novo corpo - em nossa existência, em nosso modo de sentir, de pensar, de agir etc." (Rolnik, 1993, p. 242). Desassossegar-se pelo encontro.

Desassossegados, buscamos escutar o que se perguntava a estagiária: - Que outras existem dentro de mim que são acordadas quando o canto de vida ecoa no meu corpo? Que outras mulheres trancamos nos corpos das mulheres presas, nas vidas aprisionadas?

Amotivação da estagiária com a escolha do teatroprisão está relacionada com sua implicação clínicosócio-econômico-político-libidinal (Baremblitt, 2012) com um modo de fazer Psicologia. Ela queria viver clandestinamente a história de vida das mulheres presas, não no sentido de se colocar na vida delas, empaticamente, representacionalmente, mas de viver no seu corpo outros corpos, tantas mulheres quantas a multiplicidade do viver permite. Implicava-se também com o desejo de produzir nas mulheres esse desejo de viver clandestinamente outras mulheres, de experimentar a multiplicidade de corpos, de deixar-se marcar pelos encontros: cicatrizes e veias abertas da diferença. Que vozes deixamos vazar nessas marcas? Que linguagem tem essas cicatrizes, que língua estrangeira elas nos ensinam?

A aspirante a psicóloga chega ao presídio feminino cheia de dúvidas e expectativas. Entra na sala da gestora, e essa pede para que ela espere. Em seguida, a estagiária observa uma cena violenta que, de tão absurda e abusiva, parecia mais uma cena mal executada. Reprodução: Ato 1. Entra uma agente carcerária levando uma apenada pelo braço: "você enviou uma carta dizendo para uma amiga se passar por sua irmã para conseguir o direito de visita", afirma a gestora. "Não senhora, ela é minha irmã", diz displicentemente a apenada. A gestora grita e bate fortemente na mesa "não minta para mim". Eu me encolho no sofá. A cena continua em tom cada vez mais violento e sem qualquer chance de defesa para a apenada. Ato 2. Ainda sob a tensão da cena anterior, a gestora me olha como se nenhum evento anterior tivesse acontecido e me diz: "preciso atualizar os prontuários das presas, você pode começar por isso!". Stop! Isso não era para constar no script. Precisamos ensaiar o papel do estagiário de Psicologia. "Não, meu estágio não contempla esse tipo de atividade. Minha proposta é trabalhar com grupos, ou seja, trabalhar diretamente com as presas", afirmo cautelosamente, temendo que outra cena se arme. Percebendo que poderia ir mais adiante, continuei explicando para a gestora o propósito de meu trabalho. A gestora muda de tom e afirma estar precisando de psicólogo, precisa 
"dar um jeito" nas presas. Stop! É isso que os atorespsicólogos fazem? Meu papel não era "dar jeito" em ninguém. Todavia, disfarço o sorriso de satisfação quando ela me fornece dez nomes de apenadas para que eu inicie minhas atividades. Cena encerrada.

A estagiária é convocada a representar o papel tradicional do psicólogo, é isso que a instituição espera que ela faça: reproduza palavra por palavra o textocontrole, o texto-adaptação, o texto-reinserção social; a Psicologia como disciplina da normatização (Foucault, 2002). Entretanto, como amadora que era, acreditava que iria desempenhar mal esse papel, errando as falas, trocando os verbos, mudando as posições. Para desempenhá-lo, buscou conhecer um pouco da realidade: quantos e quem eram os atores; que papéis desempenhavam; como era o palco; que recursos possuíam os atores para representar seus papéis. Não se contentava em seguir um script que já estava lá, pronto, e que foi construído ao longo da história da prática psicológica, uma prática tradicionalmente individual e diagnóstica ou centrada no grupo como modo-indivíduo (Barros, 2007). Como não conseguia decorar as falas e todo o arsenal técnico dos atores psicólogos, improvisava as falas, e os tempos, e o atuar. Experimentava outro papel: estagiária-aprendentecartógrafa. Por meio da cartografia, ela acompanhava atenta e cuidadosamente os processos em curso, mapeando o território existencial dos atores e atrizes: espaço-corpo, espaço-afeto, espaço-máquina, espaçoimanente, espaço-imagem, espaço-não espaço. Espaço não-lugar (Augé, 1994).

Buscamos mapear as redes de força que se desenhavam no atuar desses artistas, a dança cambiante que lhes fazia ora atrizes-sujeitos, ora atrizes-assujeitadas (Barros, 2007). Para tanto, não nos interessava uma prática intimista, voltada à interioridade (Baptista, 2000). Afinal, o teatro falava do mundo, falava de mundos, falava de outros do mundo. Falava desse outro diferente, desconhecido, estrangeiro que nos sacode, nos incomoda, nos violenta, que jamais nos será familiar. E eis a sua potência, ser sempre errante, inquieto, incomodado. "Um outro que não é nunca um eu, que permanece sempre como o inacessível, como o fora absoluto. ... Pois só assim haverá experiência verdadeiramente" (Levy, 2011, p. 43).

Durante a pesquisa-cartografia-experimentação, redescobrimos que o presídio feminino se tratava de um teatro precário; seus atores já cansados de desempenhar os mesmos papéis fingiam nada sentir, nada ver. O palco era só uma estrutura de tijolos onde se entulhavam corpos, pois eram muitos atores para pouco espaço. Eram quase cento e quarenta atores a desempenhar amargamente o papel de presas, todos com o mesmo figurino: uma farda que lhes tirava os traços de singularidade, traços de mulher. Elas contestavam, mas a direção desse teatro acreditava que assim manteria a ordem e homogeneização da representação. Ninguém ousaria subverter o papel de presas: iguais, passivas, controladas. Essas cento e quarenta mulheres espremiam-se no palco em treze celas. Em cada cela havia três camas de alvenaria; esse privilégio, só as atrizes mais antigas ou idosas poderiam ter. As demais se distribuíam em colchões, uns por sobre os outros, ao longo da cela. Uma cela que, devido ao tamanho, deveria receber por volta de seis atrizes-presas, acabava abrigando quase o dobro de sua capacidade. Mas elas deveriam se conformar, afinal, desejaram, escolheram o papel de presas - afirmava a direção desse teatro absurdo. Essas atrizes tinham o direito de receber da família, semanalmente, os materiais destinados à sua higiene e alimentação. Contudo, para manter uma rotina e evitar excessos, a direção restringia a entrada de certos alimentos e materiais de higiene, a exemplo de perfumes, frutas cítricas, biscoitos etc. A alimentação era restrita, entretanto, elas não podiam reclamar, pois, diariamente, recebiam uma "quentinha" que custava aos cofres públicos uma boa soma em dinheiro, para justificar os altos gastos com as atrizes e atores desse teatro. Nos bastidores diziam que as "quentinhas"

estavam quase sempre azedas, todavia, quem ousava reclamar de tão afortunada benesse? Aquelas que tinham a sorte de receber os materiais de higiene e alimentação da família ainda passavam melhores dias. Contudo, a maioria das atrizes desse teatro não recebia recursos da família e, a fim de prover suas necessidades, acabava prestando serviços às demais, na forma de faxina, de serviços de manicure ou cabeleireira, na confecção de produtos de crochê, desenhos em cartas, dentre outros. Afinal, nem só de um papel vivem as atrizes, como queria essa direção. Outro grupo desempenhava o papel de agentes carcerárias. Elas tinham um pouco mais de regalias, embora tão presas quanto as outras. Havia ainda duas mulheres representando o papel de auxiliares de enfermagem, uma representando o papel de médica pediatra e outra ainda de assistente social, que, ao que parece, vinham pouco aos ensaios. Transitam ainda pelo teatro grupos voltados à qualificação teatral, uma espécie de oficina de ressocialização para formação de atores presos: ensinam-lhes artesanato, alfabetizam-os, incutem-lhes uma crença religiosa.

Esse teatro-prisão está engessado demais, velho demais: os atores só repetem e repetem suas falas, seus papéis, ninguém experimenta outros lugares, outras 
posições. Essa constatação inquieta a aspirante a psicóloga, pois, no teatro-Psicologia, ainda é comum uma prática psicológica engessada, fortemente atrelada à noção de atendimento individual, à avaliação psicológica e ao diagnóstico. Então, grita: $\mathrm{Eu}$ desejo romper com esses espaços territorializados, desejo também cometer um crime, matar a função: função-psicólogo, função-preso, função-agente carcerário, função que burocratiza, engessa, e impede a abertura para a invenção, para a metamorfose, para o movimento gerado no encontro com o outro - o que, na Análise Institucional, chamamos funcionamento, que é esse descolamento de um modelo de saber-fazer, de uma forma-função pronta. Recuso os enunciados sobre o ser atriz presa, agente carcerária, auxiliar de enfermagem, assistente social ou psicólogo. Desejo criar. Desejo subverter esses papéis, mesmo que minimamente, molecularmente, agenciar com a linguagem novos sentidos, novas composições.

Como amadora, ela não sabia representar o teatro-clássico, com suas formas platonicamente embelezadas e acabadas; foi procurar na arte experiências que the possibilitassem essas novas relações de agenciamentos, novas relações de sentir, de ver, de pensar. Lembrou-se da leitura que mostra como a arte, por meio da pintura moderna e sua recusa à não representatividade, liberou a cor para produzir as mais diversas sensações; "novas relações de agenciamento entre as cores, a tela, o observador e o quadro" (Saidon, 2008, p. 54). Então, convidou para participar dessa viagem o grupo sugerido pela gestora, o grupo das atrizes-presas-amadoras; aquelas em que, segundo a gestora, a estagiária precisava "dar um jeito"; aquelas, que, ao que parece, também não levavam jeito para representar o teatro-clássico. Para fins de facilitar os encontros-ensaios, dividiu o grupo de dez atrizes-presas-amadoras em dois grupos de cinco, tendo em vista que o espaço que ocuparíamos era pequeno. Esses dois grupos de atrizes-presas tinham em comum o fato de representarem no teatro o mesmo papel: histórico de múltiplos encarceramentos e ausência familiar - a maioria não recebia visita. $\mathrm{Na}$ medida em que avançavam os encontros-ensaios, nosso teatro-oficina-amador foi crescendo, agregando novos membros, geralmente vindo do convite das próprias atrizes-presas. Muita gente passou por esse teatro; gente vinha, voltava, éramos grupos errantes. A proposta desse teatro-oficina-amador era construir dispositivos - sendo ele próprio um dispositivo - para permitir que outras vozes fossem produzidas, vozes múltiplas, caóticas, paradoxais. Nosso teatro utilizava a arte em oficinas com filmes, literatura, poesia, música, pintura, teatro. A arte como dispositivo para criar acontecimentos e devires. Acontecimentos que se davam ao acaso e que geravam o novo, o singular, a diferença. Um acontecimento: uma gota que cai e desorganiza; uma frase dita várias vezes que se repete diferente em nós; um personagem que nos empurra para fora de nós, produzindo uma sensação nunca antes vivida; uma música, um livro, um amor que nos faz experimentar outros tempos, tempo sem passado, sem presente, sem futuro, um tempo suspenso. Dito em outras palavras, acontecimento: tudo aquilo que escapa ao que está organizado, instituído, estabelecido.

Os nossos encontros-ensaios eram norteados por alguns temas geradores, temáticas tais como ressocialização, experiência de viver na prisão, visita íntima, direitos e deveres das apenadas, relações de afeto na prisão e fora dela, corpo, história de vida, perspectiva de futuro, sonhos, acontecimento, ajuda mútua, redes de apoio social etc. Buscamos sempre experimentar o que o encontro-ensaio do dia nos apresentava, para que caminhos nos levava e o que poderia ser potencializado ali. Nossos grupos não desejavam identidade, representação, papéis; a ideia, ao contrário, era desconstruir os papéis estabelecidos, as formas de representação instituídas, revirando, desorganizando o corpo a partir do encontro com o outro e com outros modos de pensar.

Para Deleuze (1988), o pensamento só ocorre quando é violentado pelo encontro, por algo que o force a pensar. Sem essa violência, o pensamento fica preso à reprodução dos modos de subjetivação dominantes. O pensar é, pois, um artista de circo, um clown, um palhaço, alguém que brinca de produzir um mundo a partir de seu encontro com o público; alguém que não se deixa fixar, um alguém sempre nômade: "Nesse sentido, pensar é uma possibilidade, algo que pode ou não acontecer, dependendo da ocorrência e da força dos encontros" (Levy, 2011, p. 123).

A estagiária jogava esse jogo arriscado, apostava suas fichas, esperava acontecimentos, acontecimentopensar-desejar-afetar-movimentar. Ela sabia que a qualquer momento um novo corpo nasceria, um corpo-animal-mutante, um corpo que não teria forma, nem validade, um devir corpo. Assim, deixava o corpo-bicho das mulheres ser entregue ao movimento dos encontros, ao festim da morte de um corpo e ao nascimento de outro (Rolnik, 1996). Ela também vivenciava esse processo. Seu corpo, por diversas vezes - e até enquanto escrevia -, se viu tomado por um movimento desconhecido, por um mal-estar que lhe fazia questionar certezas, limites, prática profissional.

Os encontros-ensaios passaram a incomodar uma parte do elenco, sobretudo algumas atrizes-agentes carcerárias, as quais, por não saberem representar outro papel, senão a forma-função autoritária, 
burocrática e de poder, acabam tentando limitar os possíveis encontros. De tanto representar violência, de tanto controlar e disciplinar a atuação das atrizespresas, a equipe desse teatro absurdo tinha produzido uma atuação-representação caricatural, grotesca, de mau gosto. Eram sempre as mesmas caras de medo que pareciam máscaras de carnaval: olhos que não sabiam ver o outro, apenas reproduzir uma atuação esperada, vigilante; bocas que só falavam o que estava exatamente previsto no script - bocas que temiam as palavras. Era uma cultura de desconfiança que obrigava também as atrizes-presas a controlar a fala das outras, o gesto das outras, o corpo das outras. E o medo as perseguia pelos cantos do teatro, pelo teto, pelo chão, pelas vigas, pelos olhos. Medo não somente da atuação disciplinar da direção e atrizes-agentes carcerárias, mas também da ação vigilante das próprias atrizes-presas; cada uma tinha que se mostrar boa atriz para permanecer ilesa naquele teatro. Ninguém deveria ousar falar a mais ou a menos do que estava programado, ninguém deveria fazer um gesto ou movimentar o corpo de forma diferente, singular, fora da forma ensaiada, sob pena de quebrar o segredo: o segredo do fracasso daquele teatro absurdo - o segredo de que, embora ensaiasse e ensaiasse, decorasse as falas e os gestos e o tom, e repetisse e repetisse, ninguém teria aprendido de fato seu papel. Era preciso esconder o segredo da plateia e dos atores, era preciso que esses seguissem acreditando na competência daquele teatro-prisão.

A aspirante a psicóloga foi pouco a pouco desvendando aquele segredo, percebendo que aquelas atrizes eram tão amadoras quanto ela e nisso poderia residir sua potência: estampar a falência do teatroprisão. Nos encontros-ensaios com essas atrizespresas-amadoras, ela tratou de construir um espaço de troca, de confiança, um espaço para que elas pudessem rasgar o script, pedacinho por pedacinho, e reinventar o teatro: outras falas, outros gestos, outros tempos, outros espaços. Elas passaram a falar das dificuldades de representar o papel de presas, das privações que esse papel exigia: proibição de uso de vestimenta própria, limitação de visita social e íntima, limitação na entrada de alimentos e material de higiene, castigo, afastamento familiar, ociosidade etc. Elas estavam cansadas de tantas privações. Porém, se conformavam e ensaiavam e ensaiavam seus papéis, pois ainda acreditavam no engodo desse teatro de formar atrizespresas-ressocializadas. Ato 3. - Encontro-ensaio sobre a temática ressocialização. Roteiro: livre. Entra a primeira atriz e diz: "Antes de ser presa eu era muito explosiva; agora, tenho medo do castigo e penso duas vezes antes de brigar". A outra mexe a cabeça em tom confirmativo e complementa: "A primeira vez que eu caí na prisão era como se eu tivesse em casa, tinha de tudo aqui. Entrei e saí rápido. Quando eu saí voltei a fazer a mesma coisa, não tive medo de voltar pra cá". Uma atriz-presa olha desconfiada e acrescenta: "Eu não vou mentir. Eu gosto de ter as coisas. Gosto do meu cantinho, de comprar minhas coisas. Tenho que me virar, né? Se só aparece isso, vou fazer o quê?" Segue outra e outra, todas desejantes de apresentar suas histórias:

Comigo foi assim: eu nunca tinha me envolvido com droga. Meu marido era traficante, mas não deixava eu mexer com isso. Sendo que um dia ele precisou que eu fizesse uma entrega, era só aquela entrega, porque a pessoa que ia fazer não teve como ir. Eu aceitei. Deu errado, mas eu acho que se tivesse sido fácil eu tinha continuado e ia acabar pegando uma pena maior ou morrido, não é verdade?

Outra atriz-presa com riso nervoso fala:

Eu caí na prisão umas dez vezes já. Entro e saio logo. Eu passei por aquelas casas de criança-presa, a senhora sabe como é? Às vezes, eu passo um bom tempo fora, mas aí, quando eu uso droga, passo num sei quantos dias na rua e acabo voltando pra cá. Quando eu não tô usando droga, eu gosto de trabalhar de flanelinha, fazer faxina, mas aí, quando uso, eu fico perdida e acabo caindo aqui de novo.

Outra atriz-presa observa de longe a discussão e pergunta: "Ressocialização?". Olha fixo nos meus olhos e questiona: "A senhora acredita em ressocialização?". Esboço algumas palavras na tentativa de ganhar tempo e pensar numa resposta. Ela não espera, parecia ansiosa por falar: "Imagine prender um cachorro, agora imagine deixar ele sem comer, bater nele, deixar ele trancado, agora imagine quando solta esse cachorro, o que ele vai fazer? Primeira coisa é morder a canela de quem tiver por perto". Calamos, todas suspensas, atônitas diante daquela revelação. Enquanto eu me recuperava do incômodo daquela situação, uma atriz-presa comenta:

É, eu penso assim: se a gente aprendesse um trabalho, ai tudo bem. Eu, por exemplo, queria trabalhar com comida, fazer salgadinho, sonho em ter uma cozinha. Já podia aqui tá aprendendo a cozinhar, porque quando saísse eu já tinha uma coisa pra fazer.

Paradoxo: as atrizes-presas reproduzem os discursos que reforçam o lugar do teatro-prisão como "lugar de passagem" para uma "vida nova". Reproduzem o discurso religioso de culpabilidade. Contudo, quando esquecem seu script de atrizespresas e se veem como mulheres, veem seus corposbichos-cachorros violentados, expostos, loucos para morder a canela de alguém, libertarem-se. Nesse encontro-ensaio, a estagiária analisa: embora 
muitas atrizes-presas atribuam ao teatro-prisão esse elemento ressocializador, possibilitando-as, por meio do sofrimento, pensar, desejar uma "vida nova", no próprio paradoxo de seus discursos, percebemos que não é o teatro-prisão que produz esse desejo, tampouco as privações sofridas, nem o medo de reincidir, mas o desejo de sair do processo de marginalização, de exclusão, o desejo de experimentar outras possibilidades de vida. Assim, é inconsistente o argumento que atribui relação direta entre privação e temor de novo encarceramento, uma vez que são outras as circunstâncias, como o uso de drogas, a necessidade de consumo, a necessidade de subsistência, a alienação afetiva, dentre outras questões, que empurram as mulheres para as práticas delituosas.

A própria noção de ressocialização por si só já é questionável, haja vista que socializadas as atrizespresas já estão, socializadas com os seus valores, hábitos, com os costumes de sua comunidade - seu modo de falar, comportar, viver. Não há como conceber esse teatro-prisão como espaço de "ressocialização", como ressalta Carvalho Filho (2002).

Trata-se mais de um lugar de "mortificação do eu" (Goffman, 1974, citado por Godoi, 2011), no qual as atrizes-presas são submetidas a todo um processo de despersonalização e mutilação de identidades, mutilação essa vivenciada com o afastamento do meio externo, com a perda dos objetos pessoais, da intimidade, com a submissão a procedimentos humilhantes de revistas periódicas etc.

A instituição-teatro-prisão demandava a todo o momento que as atrizes-presas mantivessem um baixo tom de voz; respeitassem umas às outras (quando contraditoriamente recebiam punição); não revidassem ou questionassem as decisões institucionais; se vestissem moralizadamente (o que reforçava a necessidade de uso do figurinofardamento) etc. Contudo, o que se questiona é o fato de que essas normas de conduta, com o propósito de formar atrizes-presas-ressocializadas, fazendo-as aptas a atuar em outros teatros da sociedade, nada dizem à vida efetiva delas: são normas produzidas muito mais para normatizar, domesticar, do que propriamente produzir vida e autonomia: "Nós precisamos encarar essa verdade, ver que a pena em execução é absolutamente incompatível com qualquer propósito ressocializador. Pelo contrário, a pena dessocializa" (Silva, 2010, p. 34).

Não estamos, com isso, desconsiderando a necessidade de haver uma responsabilidade por parte das pessoas acerca de seus atos. Contudo, não se pode confundir responsabilização com arbitrariedade, violência, castigo. É necessário sim pensar em estratégias que possibilitem uma reflexão acerca do ato praticado, pensando outras formas de vida, outros modos de lidar com o outro, de produzir laço social, enfim, estratégias libertárias e autônomas que cumpram o propósito de responsabilidade pelo ato praticado. Como atingir esse propósito se apartamos as atrizespresas de seus familiares, se reforçamos ainda mais o rompimento do laço social, o afastamento, a exclusão? Ato 4. - Encontro-ensaio sobre a experiência de viver no teatro-prisão. Roteiro: livre. Entra a primeira atrizpresa em cena: "O que eu mais sinto falta aqui é da minha família. As minhas amigas não vêm me visitar porque não pode, né? E a família da gente nem sempre pode vir, porque custa a passagem e às vezes não tem". Outra atriz-presa complementa: "Eu que não quero que minha família venha aqui. Minha mãe manda minhas coisinhas e a gente se encontra na liberdade. Isso aqui não é lugar pra ela". Em tom confirmativo, entra em cena outra atriz: "Minha mãe vem pra visita, mas fica do lado de fora. Não quer passar pela revista. Eu entendo, porque só a gente pra aguentar. Às vezes as agentes me deixam falar com ela pelas grades. Mas é só assim". Triste, uma atriz entra em cena com a seguinte fala:

Sabe como a gente sabe notícia da familia? Pela televisão. Esses dias as meninas da nove [fazendo referência ao número da cela] gritaram por mim, porque viram na televisão um menino parecido com meu filho, sendo preso. Fico com coração apertado toda vez que assisto televisão, pensando já no pior.

Como pensar em restabelecer os laços sociais, se cada vez mais criamos barreiras de acesso, fazemos revistas humilhantes, fazemos do familiar cúmplice, perigoso, culpado? A experiência da atriz-estagiária mobilizou muitas inquietações. Ela teve que lidar com o sentimento de impotência diante do imponderável sistema; a angústia de ver as violações de direitos institucionalizadas; de ver que estava fazendo parte de uma instituição em que não acreditava, que criticava, que queria extinta. Foi inquietante a tarefa de conciliar, de um lado, o desejo de continuar sonhando que seu encontro com as atrizes-presas, que os filmes, os personagens, as palavras, as músicas, pudessem produzir nas mulheres algo novo, outro modo de pensar, de sentir, desejar; e, por outro lado, a consciência de que estava tão presa quanto elas, presa a um sistema que lhe impedia, inclusive, de sonhar com a liberdade. Embora seja falacioso acreditar que a inserção do ator-psicólogo no teatro-prisão possa promover alguma mudança radical, ou as famigeradas palavras bem-estar, qualidade de vida, ressocialização, acreditamos que é importante somar forças para pensar em outro texto, em outro contexto para esse teatro, para se ocupar desse lugar invisível, para gerar 
encontros que possam movimentar afetos, movimentar desejos, movimentar formas de pensar, violentar formas de pensar, devir-pensamento. O que desejam essas atrizes-presas quando o palco é o mundo? Esse foi o mote de um dos nossos encontros-ensaios. Ato 5. Entra em cena uma atriz-presa reincidente:

Na primeira vez que eu sai daqui, eu fui chamada pra trabalhar de cozinheira. Ganhava a metade de um salário, mas tinha que pagar meu vale transporte. Pedi pra me ajudarem com o transporte, mas não deu certo. Eu ia todo dia e trabalhava até às cinco da tarde. Chegava cansada. No final do mês o dinheiro era pouco. Um dia, fui passando lá perto de casa e me chamaram pra uma entrega. Não voltei mais pro trabalho da cozinha.

Esse encontro-ensaio e outros que transversalizam essa temática foram particularmente inquietantes. Percebemos como elas desejavam interpretar outros papéis, atuar em outros palcos: estudar, abrir um negócio, montar um ateliê, cuidar dos filhos, dos pais, trabalhar de manicure, camelô. Porém, quando elas tentavam interpretar esses outros papéis, tinham sempre um riso envergonhado colado em suas bocas ou o riso da plateia descrente dessas atuações. Isso era especialmente notório quando se tratava de atrizespresas que interpretavam o papel de reincidentes, pois, para elas, o desejo, o sonho parecia ainda mais vergonhoso, ilusório, distante. Afinal, se você já teve oportunidade de atuar noutros papéis e noutros palcos e a plateia não gostou, a culpa é sua. Você deveria ter se esforçado mais, ensaiado mais. A plateia está ali, quieta, estática, e do ator, e somente do ator, depende a responsabilidade da interpretação.

A experiência da atriz-estagiária mostra que, apesar de os filhos serem um elemento que dificulta a mudança e o movimento das mulheres no mundo, as mesmas encontram estratégias para lidar com essas dificuldades - mesmo que essas estratégias recaiam em práticas ilícitas. Paradoxalmente, as mulheres necessitam cuidar dos filhos - desenvolvendo uma postura reconhecida socialmente como de mãe responsável - e movimentar-se no espaço, construir outras possibilidades de vida, o que, devido à exclusão e estigmatização, as leva, algumas vezes, a recair em práticas criminosas. Pois bem, com atrizes fatigadas de tantos ensaios, longe da família, preocupadas com os filhos e, ademais, sendo vigiadas, cobradas em sua atuação, tudo fica por um triz, por um fio, por uma palavra, por um gesto.

Certo dia, a estagiária olha para a estrutura do teatro e vê suas paredes rachadas; cai uma fina poeirinha do teto, que agora é cada vez mais constante. Tudo está prestes a ruir. Mas, como o show tem que continuar, logo se reveste de cimento e se cobrem as marcas rachadas com tinta branca. Porém, as atrizespresas estão cada vez mais desconfiadas da farsa, e isso acirra ainda mais os ânimos. Ato 6. Na cela do castigo, uma atriz-presa pede, discretamente, para que as companheiras da cela vizinha passem um pacote de bolacha, pois ela está com fome. As colegas passam o produto. Percebendo o acontecido e, temendo que a equipe do teatro descubra a contravenção e puna irrestritamente as demais atrizes-presas, mesmo aquelas sem envolvimento com o ato, elas começam a bater as grades, tentando chamar a atenção da equipe do teatro, sobretudo das atrizes-agentes carcerárias, para a irregularidade. Noutra ocasião, uma atriz-presa passa mal, sente fortes dores na cabeça e no peito, desmaia. As colegas de cela pedem ajuda às demais no sentido de bater as grades a fim de chamar a atenção da equipe. Poucas colaboram. Depois de mais de uma hora gritando e batendo grade, finalmente a equipe aparece. Por falta de colaboração no "bater grade" e gritar, era tarde demais. A atriz é levada ao hospital e nele vai direto para a Unidade de Terapia Intensiva (UTI).

A estagiária pensa que é preciso escrever outro texto, um texto coletivo; é preciso reafirmar a potência do coletivo que se encontra desgastada pelo controle, pela vigilância; enfim, é preciso "bater grade" para chamar atenção das atrizes-presas, colocando seu corpo-bicho-cachorro para atuar. Entre os ensaios, as atrizes-presas contam que, antes, elas eram mais unidas. Certa vez, tentaram organizar uma rebelião. Os ensaios para a rebelião aconteciam na lavanderia, local mais reservado da vigilância institucional. Aconteceria assim: no dia da visita, as atrizes-presas interpretariam o sequestro de algum parente. Em troca, pediriam melhores condições de "moradia" e alimentação. A rebelião não aconteceu, pois adiaram e acabaram sendo descobertas. Elas contam que, atualmente, até mesmo os abaixo-assinados estão difíceis de acontecer. Ninguém quer colaborar. Todas têm medo. $\mathrm{O}$ medo parece ter contaminado o elenco desse teatro e, com medo da contaminação, cada uma se protege com isolamento e desconfiança. Nos corredores, ouvem-se rumores de que não se pode confiar em ninguém. $\mathrm{O}$ vírus da desconfiança passeia pelo ar do teatro e, cada vez mais, o ambiente se torna claustrofóbico. Algumas atrizes se queixam de que estão enlouquecendo, falam sozinha, vão ao banheiro para chorar, não conseguem controlar $\mathrm{o}$ choro. Os rumores são de que existem muitas " $\mathrm{X} 9$ " ou "cabuetas", como se diz na linguagem das atrizespresas. Observam, escutam, assistem atentamente aos ensaios para que, ao menor deslize, comuniquem à direção do teatro. 
Existe todo um pré-texto por parte das atrizespresas que estabelece o que é e o que não é permitido no âmbito do teatro-prisão. Isso se acentua ainda mais no grupo em que a maioria não recebe visita, na medida em que essas precisam "se virar" dentro do teatro - o que pressupõe nem sempre agir conforme as normas institucionais. Ademais, para essas mulheres, a família são aquelas pessoas que elas confiam dentro do presídio e, se a sociedade falha com elas, as exclui, suas companheiras não podem repetir a mesma situação. Isso nos chama a atenção para o fato de que o dispositivo da fiscalização (Foucault, 1977) aparece mascarado no aspecto individual, ou seja, aquilo que é forjado pela máquina disciplinar é colocado na ordem do individual, como se fosse uma questão do sujeito, que precisa vigiar o outro, pois nele reside o perigo, a desconfiança.

O dispositivo da fiscalização perpassa todos os envolvidos no teatro-prisão: relação direção-atrizes, atrizes-presas/atrizes-presas, atrizes-presas/atrizesagentes carcerárias e vice-versa. As instituições totais atingem controlador e controlado (Goffman, 1974, citado por Carvalho Filho, 2002). Isso significa que, enquanto as atrizes-agentes carcerárias sentem-se ameaçadas, temendo o perigo emanado pelas atrizespresas, diante do estereótipo de periculosidade associado ao texto-atuação dessas, as atrizes-presas, por sua vez, associam as atrizes-agentes carcerárias a figuras arbitrárias e desumanas, sentindo-se ameaçadas com sua presença.

Continuando nossa história sobre a máquinadisciplinar no teatro-prisão, máquina regulada para a produção de atrizes-presas-normatizadas, destacamos que ela recebe ainda contribuição do discurso religioso, o qual figura como o principal financiador nessa política do controle. O discurso religioso há muito já se incorporou ao texto interpretado pelas atrizespresas. Os contos-sonhos que elas relatam têm sempre deuses e seus milagres como heróis, como fazedores do conto-sonho. E, como os deuses das religiões são também punitivos, a eles cabe toda sorte de peripécias penais: os deuses são também juízes. Entre cortinas abertas, a estagiária ouvia as falas: "Vou mudar de vida porque Jesus está me ajudando!"; "O Juiz vai mudar minha sentença por obra de Deus!", "Jesus vai me ajudar!", "Eu errei, mas Deus está me ajudando!". Assim, os seus contos-sonhos de atuar noutros teatros e noutros papéis ficam sob a responsabilidade dos deuses fazedores de contos-sonhos.

As atrizes-presas só interpretavam o texto que esses deuses-roteiristas criavam. Fantoches nas mãos dos deuses-contistas, como o discurso religioso tenta fomentar. Com isso, a crença religiosa sustenta a ideia de que os deuses ajudam, escrevem roteiros e dão pistas de atuação. Se a atriz não obteve êxito em sua atuação, foi porque ela não se esforçou devidamente e, portanto, mais uma vez a questão se volta para o plano individual, para a culpabilização do sujeito. Os deuses das religiões são também críticos de teatro. De deuses críticos de teatro aos quase-deuses diretores do espetáculo, o dispositivo disciplinar vai ganhando força e consistência; o texto-vida vai se tornando cada vez mais representacional, dele pouco dependendo a experimentação dos atores e atrizes.

A vida nua (Agamben, 2004, citado por Rosa, 2007) é a vida matável, a vida que pode ser exterminada sem que se configure crime ou sacrifício, que se pode deixar morrer: a vida do homo sacer, aquela desprovida dos direitos básicos; é o lixo humano, não compondo o universo da vida a ser preservada, do deixar-se viver na estrutura do biopoder ${ }^{2}$ (Foucault, 2010), perfazendo a exceção contemporânea.

A partir dessa reflexão, podemos pensar na vida marginalizada dos atores e atrizes-presas - vida descartável, que se pode deixar morrer. Nota-se que esses sujeitos, antes mesmo de ingressarem nessas instituições de confinamento, já estavam inseridos numa lógica de exclusão social. Com isso, falar em vida nua pressupõe explicitar um processo de marginalidade que ocorre durante a vida desses sujeitos, para além do momento das práticas de crimes ou delitos. Vida nua que se pode privar do contato com o outro, de alimentação digna, de cuidados básicos de higiene, de saúde; que se pode submeter a castigos em celas sem iluminação e visibilidade externa. Vida nua que começa desde o nascimento e "termina" no processo sem fim de idas e vindas aos teatros-prisões da vida.

É notório como essa vida nua já entrou "formalmente" na lógica do estado de exceção regulamentado. Arossi (2009, consubstanciando-se em Wacquant, 2001) discute que as prisões brasileiras têm seguido a lógica de que é preciso aprisionar e não antes socializar bens. $\mathrm{O}$ autor destaca a paradoxal política adotada pelo Estado brasileiro, que pune duplamente a população pobre, uma vez que, diante da impossibilidade de sobreviver na cidade, resta a essa população a alternativa de se inserir no mercado informal ou no mundo do crime.

Nos encontros-ensaios com as atrizes-presas, o texto se repetia: "Quando se cai uma vez aqui, as coisas ficam mais dificeis que antes. Se a gente não conseguia emprego sem passagem pela polícia, imagine ex-detenta! Ninguém quer saber de nós, não!". Essa trajetória de encarceramento marca inúmeras famílias pobres no Brasil. Na experiência do teatro-prisão, era comum ter notícias de famílias 
quase inteiras com histórico de criminalidade. Uma atriz-presa relatou durante um dos encontros-ensaios que, antes, o teatro-prisão feminino era limitado, isto é, poucas mulheres faziam o papel de atrizespresas e, quando o faziam, resultava no texto-crime envolvendo, principalmente, atentados contra a vida. Para ela, atualmente, os teatros-prisões femininos encontram-se superlotados em razão da entrada das mulheres no texto-tráfico de drogas, sobretudo pela maior oferta de "trabalho" e, também, em decorrência da entrada de seus maridos e companheiros nos teatros-prisões da vida, os quais, com o tráfico de drogas, se responsabilizavam pela manutenção da família. Com os maridos interpretando presos, as mulheres acabam ocupando o lugar dos mesmos no que diz respeito ao comércio de drogas, diante da necessidade de continuar provendo a família.

Muitas atrizes-presas se encontram no teatroprisão por privação de condições mínimas de vida, por necessidade de subsistência que as levaram a praticar determinados atos. Porém, outras tantas estão presas por amor - por envolvimento afetivo com homens que realizam alguma atividade criminosa -, por poder, por dinheiro, por desejo de consumo. Algumas destacam que o motivo é justamente o desejo de possuir bens materiais: roupas, casa e outros objetos de consumo.

Pensar esses processos de subjetivação pressupõe conceber a subjetividade como produzida por uma multiplicidade de agenciamentos de caráter intrapsíquico, social, político, econômico, ecológico, midiático etc. -, conforme advertem Guattari e Rolnik (2010). Esse mesmo poder sobre a vida, que produz modos de subjetivação assujeitados, alienados, consumistas, serializados, também é potência de vida - e não somente poder sobre a vida.

Em certo momento da prática, a atriz-estagiária começa a observar ensaios paralelos: um texto coletivo sendo escrito e encenado junto. Ela ouve as danças e os risos e quase sente os corpos deslizando, entregandose no palco. Esse texto fala da potência da vida, da resposta ao poder sobre a vida; fala de estratégias de resistência no interior desse teatro-prisão, das relações de amizade, do afeto, da ajuda mútua, do cuidado com o outro. Assim, embora a vida nua circulasse pelo teatro-prisão, quase trôpega, embora seu corpobicho-cachorro-magro latisse fininho, seu ranger era de vida, de uma vida nua que, fio por fio, costurava redes de apoio, de amizade, de afeto. Atrizes-artesãs de redes de apoio que, incansavelmente, trabalhavam costurando essas delicadas redes: redes das atrizestrapezistas para amparar o salto; redes jogadas ao mar para pescar desejos; redes para embalar os sonhos. Sem essas redes, como poderiam nossas atrizes sonhar com outros palcos, com outros trapézios e com outros mares para pescar?

Algumasatrizes-presas relatamquedesconheciam o teatro-prisão e não imaginavam um dia desempenhar esse papel. Para elas, as atrizes-presas eram perigosas; era assim que a televisão as mostrava. Todavia, por circunstâncias da vida, chegaram ao teatro-prisão e se depararam com mulheres que sofrem, que sentem saudades, que vivenciam o abandono. Teatro-prisãosolidão:

Eu aprendi que aqui tem muito sofrimento. Muitas mulheres sofridas, abandonadas pelos maridos, pelas mães, por filhos, por tudo aqui. O povo tem a gente como bandida, mas tem um monte de mulher sofredora. Eu estou presa por causa de um erro do meu marido e estou aqui, um ano e três meses. A justiça é muito injusta. Os traficantes ficam tudo ai na rua e as mulheres tudo presa, longe de seus filhos, de seus maridos, de suas mães. Às vezes, a gente não é abandonada, mas são as condições da mãe, dos irmãos que não podem visitar. Eu aqui não sei o que é alegria, é só tristeza, dor e saudade. (Dora, atrizpresa)

"O sofrimento pode forçar o pensamento a pensar o impensável, a criar sentidos para a dor. Não em um apaziguamento ou em uma tolerância ou em um suportar a dor e, sim, em uma transmutação em alegria" (Domingues, 2010, p. 28).

Potencialidade da criação como ferramenta de produção de vida: novo espetáculo. É esse espetáculo que desejamos ver encenado e apreendido pelo mundo. Dias (2011), respaldando-se na filosofia de Nietzsche, defende a ideia de que viver não é apenas manter-se vivo, sobreviver. Para a autora, a noção de preservação, conservação da vida, é expressão de um estado indigente, de uma limitação do verdadeiro impulso fundamental da vida que é a expansão do poder, do corpo, da potência. Um corpo quer crescer, expandir sua força, expulsar quem - ou o que - resiste à sua expansão. Portanto, todo acontecimento, toda transformação é uma luta não pela vida, mas pela potência dela derivada. A potência é justamente esse desejo de expansão, a capacidade de criar, vencer as resistências que se interpõem. Nesse contexto, a estética se apresenta como condição de criação de novas formas de existência. Isto é, a arte, a estética como possibilidade de tornar o homem artista da sua vida, fazendo dela uma obra de arte.

Dias (2011, pensando com Nietzsche, 1886) afirma que "a vontade de potência, como força de interpretação, produz sem cessar alguma coisa que não existe ainda" (p. 58), e defende a ideia de que somos criadores do mundo, pois, sem nossa interpretação, 
sem nossa intervenção sobre o real, o mundo, como tal, não existiria. Nesse caso, a arte e a estética se colocam a serviço dessa criação, dessa possibilidade de pensar, de inventar outras formas de vida.

As atrizes-presas já faziam arte antes de a arte fazê-las artistas. E elas têm desejo de arte, como a arte delas tem desejo:

Um conto de fadas são coisas que sonhamos futuramente. Uma coisa que você quer muito e precisa de muita força de vontade pra isso. Essa bonequinha aqui se chama Maria Rosa, e foi meu primeiro conto de fadas, digamos assim, porque foi minha primeira peça. E ela é importante pra mim, porque foi meu primeiro trabalho. $O$ conto de fadas é que dela eu posso crescer e ser uma grande empresária futuramente. O que eu penso quando olho pra ela é crescer, porque do jeito que eu fiz ela, eu posso fazer outras coisas mais, que minha vida possa virar um conto de fadas, uma coisa bem bonita, se torne algo novo. Tudo novo pra mim. (Irene, atriz-presa)

Às vezes, uma coisa é pequena que a gente tem ou que fez ou que praticou aos olhos de outras pessoas pode se tornar inútil, mas pra gente tem um valor maior [referindo-se a certas coisas que elas produzem]. Aqui dentro, eu aprendo isso a cada dia que se passa e a questão de relevar as coisas. (Isis, atriz-presa)

A cortina se fecha. A plateia aplaude. Terá a estagiária ouvido as vozes das atrizes-presas? O que será que acontece no camarim após o espetáculo? O que nós, plateia, vamos conversar no caminho para casa? As atrizes-presas aguardam ansiosas as nossas críticas ao espetáculo. Que críticas serão essas?

\section{Notas}

1 O uso do termo teatro-menor faz alusão ao conceito literatura-menor pensada por Deleuze e Guatarri (1977). Para eles, três características marcam a literatura menor: a desterritorialização da língua, a articulação do individual com o político (a imanência presente nessa relação) e o dispositivo coletivo de enunciação.

2 Acerca do conceito de biopoder, ver Foucault (2010).

\section{Referências}

Arossi, G. (2009). As prisões da miséria. Controvérsia, 5(1), 59-61.

Augé, M. (1994). Não-Lugares: introdução a uma antropologia da supermodernidade. São Paulo: Papirus.

Baptista, L. A. S. (2000). A fábrica de interiores: a formação psi em questão. Niterói, RJ: EdUFF.

Baremblitt, G. (2012). Compêndio de análise institucional e outras correntes: teoria e prática. Belo Horizonte: FGB/ IFG.
Barros, R. B. (2007). Grupo: a afirmação de um simulacro. Porto Alegre: Sulinas/Editora da UFRGS.

Carvalho Filho, L. F. (2002). A prisão. São Paulo: Publifolha.

Deleuze, G. (1988). Diferença e repetição. Rio de Janeiro: Graal.

Deleuze, G. \& Guattari, F. (1977). Kafka por uma literatura menor. Rio de Janeiro: Imago.

Dias, R. (2011). Nietzsche, vida como obra de arte. Rio de Janeiro: Civilização brasileira.

Domingues, L. (2010). A flor da pele: subjetividade, clínica e cinema no contemporâneo. Porto Alegre: Sulina/Editora da UFRGS.

Foucault, M. (1977). Vigiar e punir: nascimento da prisão. Petrópolis, RJ: Vozes.

Foucault, M. (2002). A Psicologia de 1850 a 1950. In M. B. Motta (Org.), Problematização do sujeito: psicologia, psiquiatria e psicanálise (pp. 133-151). Rio de Janeiro: Forence Universitária.

Foucault, M. (2010). Aula 17 de março de 1976. In M. Foucault, Em defesa da sociedade: curso no Collège de France (pp. 201-222). São Paulo: WMF Martins Fontes.

Godoi, R. (2011). Para uma reflexão sobre os efeitos sociais do encarceramento. Revista Brasileira de Segurança Pública, 5(8), 138-154.

Guattari, F. \& Rolnik, S. (2010). Micropolítica: Cartografia do desejo. Petrópolis, RJ: Vozes.

Levy, T. S. (2011). A Experiência do fora: Blanchot, Foucault e Deleuze. Rio de Janeiro: Civilização Brasileira.

Rolnik, S. (1993). Pensamento, corpo e devir: uma perspectiva ético, estético e política no trabalho acadêmico. Cadernos de Subjetividade, 1(2), 241-251.

Rolnik, S. (1996). Lygia Clark e o híbrido arte/clínica. Acesso em 10 de outubro, 2012, em http://www.caosmose.net/ suelyrolnik/pdf/Artecli.pdf

Rosa, S. O. (2007). Fazer viver é deixar morrer. Revista Aulas, 3. Acesso em 14 de setembro, 2012, em www.unicamp. br/ aulas/pdf3/28.pdf

Saidon, O. (2008). Devires da clínica. São Paulo: HUCITEC.

Silva, H. C. (2010). Estado penal e funções do cárcere na contemporaneidade: produção de subjetividade e da criminalidade. In Conselho Federal de Psicologia (Org.), Atuação do psicólogo no sistema prisional (pp. 33-41). Brasília: Autor

Submissão em: 10/02/2014

Revisão em: 30/03/2014

Aceite em: 20/042014

Gabriela Pinheiro Soares é Pós-graduanda em “Análise Institucional, Esquizoanálise e Esquizodrama: Clínicas de Indivíduos, Grupos, Organizações e Redes Sociais" pela Fundação Gregório Baremblitt e Instituto Félix Guattari. Graduada em Psicologia pela UnP - Universidade Potiguar. Fez Estágio Profissionalizante no Complexo Feminino Dr. João Chaves realizando Pesquisa-intervenção "Cartografia em Arte de Mulheres em situação de Cárcere". Atuando na pesquisa "saúde mental e subjetividade: da arte de ouvir vozes à arte de reinventar-se em uma unidade psiquiátrica". Endereço: Rua Praia Barreta, 2265. Ponta Negra. Natal/RN, Brasil. CEP 59092-230. E-mail: gabypsoares@hotmail.com 
Antônio Vladimir Félix-Silva é Doutor em Ciências

Psicológicas pela Universidad de La Habana, com formação em psicopedagogia clínica pela Escuela

Psicopedagógica de Buenos Aires. Professor do curso de

Psicologia e de cursos de pós-graduação na Universidade

Potiguar - UnP. Faz parte do Núcleo Interdisciplinar

de Estudos em Diversidade Sexual, Gênero e Direitos

Humanos - Tirésias/Universidade Federal do Rio Grande do Norte - UFRN. Coordena o Grupo de Estudos

Cartografia da Diferença e Esquizoanálise, atuando em pesquisas acerca dos modos de vida trans e nas pesquisas: "saúde mental e subjetividade: da arte de ouvir vozes à arte de reinventar-se em uma unidade psiquiátrica" e "modos de viver e fazer arte de pessoas em situação de rua". E-mail: wlady@hotmail.com

Martha Emanuela Soares Da Silva Figueiró é Psicóloga graduada pela Universidade Federal de Sergipe, com mestrado pelo programa de Pós-Graduação em Psicologia da Universidade Federal do Rio Grande do Norte, na linha de pesquisa sobre Práticas Sociais com Crianças e Adolescentes. Professora do curso de graduação em Psicologia da Universidade Potiguar - UnP. Atua na área de Psicologia Social, principalmente nos seguintes temas: Infâncias, Juventudes e Direitos Humanos,

Psicologia e Políticas Sociais (SUAS, SUS, ECA), Psicologia Social Comunitária, Psicologia e Educação e Educação à Distância. E-mail: marthaess@gmail.com

\section{Como citar:}

Soares, G. P., Félix-Silva, A. V., \& Figueiró, M. E. S. S. (2014). Teatro-menor: cartografia em arte e experimentação de mulheres em situação de cárcere. Psicologia \& Sociedade, 26(n. spe.), 89-99. 